\title{
Performance of Concrete with Fly Ash and Kaolin Inclusion
}

\author{
Afaf Ghais, Duaa Ahmed, Ethar Siddig, Isra Elsadig, Samah Albager \\ Chemical Engineering Department, University of Khartoum, Khartoum, Sudan \\ Email: afafghais2000@gmail.com
}

Received 27 August 2014; revised 23 September 2014; accepted 15 October 2014

Copyright (C) 2014 by authors and Scientific Research Publishing Inc.

This work is licensed under the Creative Commons Attribution International License (CC BY). http://creativecommons.org/licenses/by/4.0/

c) (i) Open Access

\begin{abstract}
Waste materials of environmental risks, costly landfill disposal can be utilized in cement and concrete applications. Partial replacement of cement in engineering projects reduces the cost of construction with ecological benefits. The type and mix ratio affects the strength and workability of cement-concrete matrices. This research deals with the replacement of Class F fly ash and kaolin with cement used in concrete. Replacement of $10 \%$ fly ash with cement improves the comprehensive strength of concrete in 28 days period, and the workability is increased by $53.8 \%$. The kaolin replacement reduced both the strength and workability of concrete.
\end{abstract}

\section{Keywords}

Fly Ash, Kaolin, Strength, Workability

\section{Introduction}

Addition of fly ash and kaolin to concrete offers advantages such as performance improvement, reduction of the amount of by-product materials, landfill cost and enables manufacturers to minimize mining and processing virgin materials, thereby reducing the emission of carbon dioxide.

Four basic ingredients of the conventional concrete are Portland cement, fine and coarse aggregates and water. The production of high performance concrete (HPC) needs to incorporate the supplementary cementations materials such as fly ash and kaolin in the concrete mix [1]. Low calcium fly ash (ASTM Class F) and kaolin have been widely used as a replacement of cement in normal and high strength concrete [2] [3].

In normal strength concrete, the replacement level of fly ash can be more than 50\% [4] [5], while in high strength concrete, the replacement level is usually limited to $15 \% \pm 25 \%$ [2]. The main objectives of using fly ash in high strength concrete are to reduce heat generation and to obtain better durability properties. For several cases, early strength of concrete was low, particularly where a significant portion, 30 percent or more, of the 
Portland cement was replaced with fly ash [6]. Wild et al., [7] proved that for addition of metakaolin up to 30\%, compressive strength at 28 days increased within the range of 1.53\% - 35\%. However, Priyank, et al., found that the compressive strength decreased when replacement with kaolin percentage increased. The fact is that the type of kaolin affects the concrete strength [8].

The property of concrete which determines the amount of useful internal work necessary to produce full compaction is known as workability. The workability of fresh concrete depends mainly on the material, mix proportion and environmental conditions. The use of pozzolan, such as fly ash, plays an important role in contributing to a better workability of HPC [9]. Tanaka et al. [10] found that with 10\% lesser water binder ratio, the workability of the concrete increased with an increase in amount of fly ash. Wild et al. found that workability of concrete at 0.45 water cement (w/c) decreased with increase in replacement of cement by metakaolin.

In the present study, the effect of fly ash and kaolin on concrete strength and workability were studied, and a comparison of the two binders was made.

\section{Experimental Work}

\subsection{Materials}

Kaolin materials from North Omdurman, Khartoum State and class F fly ash study sample from Road and Building Institute, University of Khartoum with the following compositions were used for the experimental work Table 1.

\subsection{Experimental Method}

\subsubsection{Concrete Mix with Fly Ash and Kaolin}

Concrete mixtures and cement paste was prepared with $(8.75 \mathrm{~kg}$ cement,18.75 kg fine aggregate, $28.13 \mathrm{~kg}$ coarse aggregate and $5.28 \mathrm{~kg}$ water ) in a ratio of (1:2:3). Fly ash was used in the proportions of $10 \%$, $20 \%$, and $30 \mathrm{wt} \%$ of the total cementitious materials. The concrete mixtures were proportioned and mixed in a pan mixer, Photo 1. For concrete kaolin mixture, the kaolin to cement replacement ratio was $10 \%, 20 \%$, and $30 \mathrm{wt} \%$.

Table 1. Fly ash and kaolin chemical composition.

\begin{tabular}{cccccc}
\hline Components \% $(w / w)$ & $\mathrm{SiO}_{2}$ & $\mathrm{Al}_{2} \mathrm{O}_{3}$ & $\mathrm{Fe}_{2} \mathrm{O}_{3}$ & $\mathrm{CaO}$ & 2.07 \\
\hline Fly & 86.5 & 4.24 & 0.07 & 1.12 \\
Kaolin & 88.60 & 0.04 & 18.07 & 0.2 \\
\hline
\end{tabular}

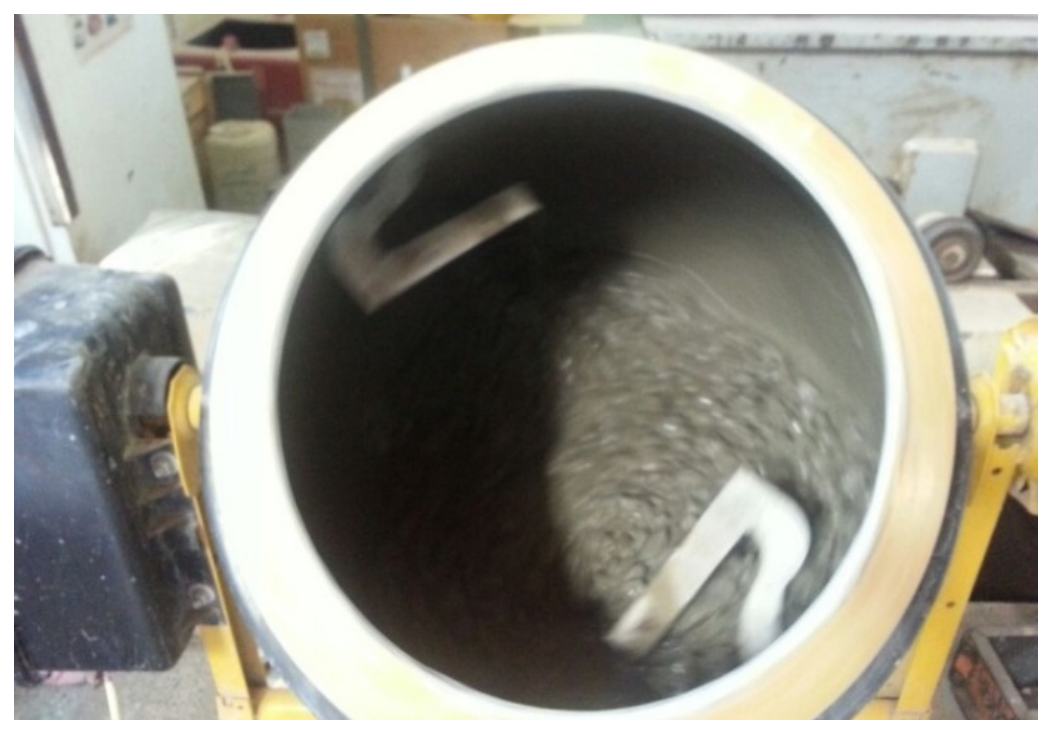

Photo 1. Pan mixer. 


\subsubsection{Comprehensive Strength}

Compaction of fresh concrete in 6 cubic steel moulds was achieved, applying Thirty-five manual strokes per layer in three equal layers. The cube dimension was $150 \mathrm{~mm} \times 150 \mathrm{~mm} \times 150 \mathrm{~mm}$. For comprehensive strength the cubes were left to dry for one day and then immersed in water, three of the cubes were left for 7 days and the other three were left for 28 , the compressive strength was measured in $\mathrm{N} / \mathrm{mm}^{2}$, using compressive testing machine Photo 2.

\subsubsection{Workability Test}

The slump test used to characterize the workability of concrete. Its apparatus consists of a mold in the shape of a frustum of a cone with a base diameter of 8 inches, a top diameter of 4 inches, and a height of 12 inches, Photo 3. The mold was filled with concrete in three layers of equal volume. Each layer was compacted with 25 strokes of a tamping rod. The slump cone mold was lifted vertically upward and the change in height of the concrete was measured.

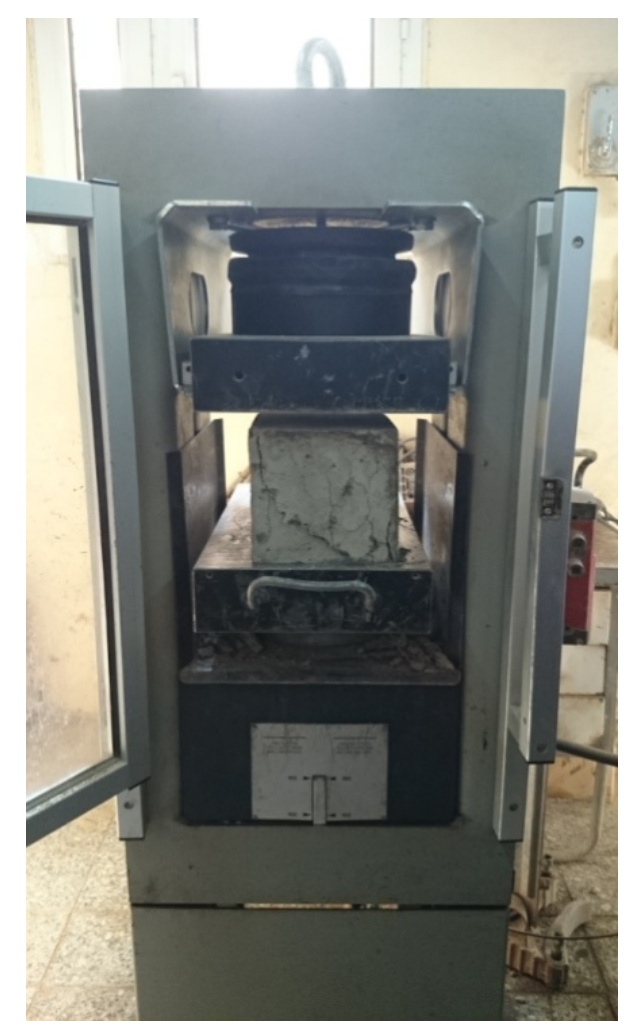

Photo 2. Comprehensive strength machine.

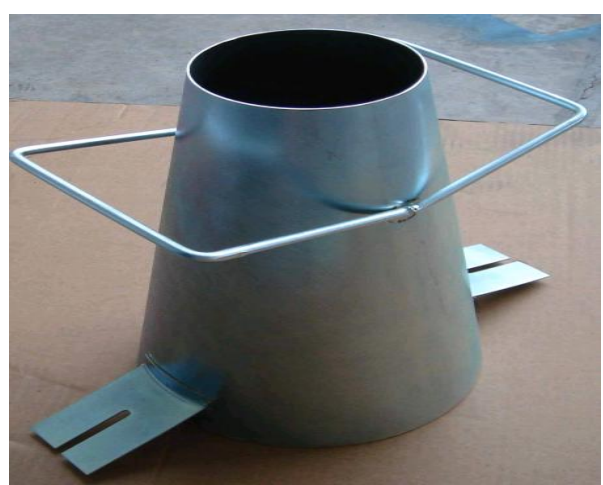

Photo 3. Slump cone mold. 


\section{Results and Discussion}

The comprehensive strength for 7 days and 28 days, and the workability of concrete with fly ash and kaolin with 10\%, 20\%, 30\% were measured. The results were shown in Figures 1-4.

For the sample where the strength was measured after 7 days, the comprehensive strength of concrete was reduced with the addition of fly ash, the strength was reduced by $10 \%, 21.2 \%, 40.8 \%$ with the addition of $10 \%$, 20\%, 30\% respectively. For the long term immeresion, 28 days, the strength increased by $4.99 \%$ with $10 \%$ fly ash, then the strength was reduced by $14 \%$ and $27.5 \%$ with $20 \%$, 30\% fly ash addition. The fact that for long term process the pozzolana materials in Flass F fly ash, react with water and cement for higher concrete strength. The best result was obtained with $10 \%$ fly ash.

Fly ash samples under study consist low $\mathrm{CaO}$ of $1.12 \%$. The reason that at early strength age (7 days) of $10 \%$ fly ash replacement to cement, the calcuim, alumunum, silicon constitutes react with water to form pozzolan complex polymer that enhance the strength of concrete mix. With increasing the replacement ratio of fly ash to

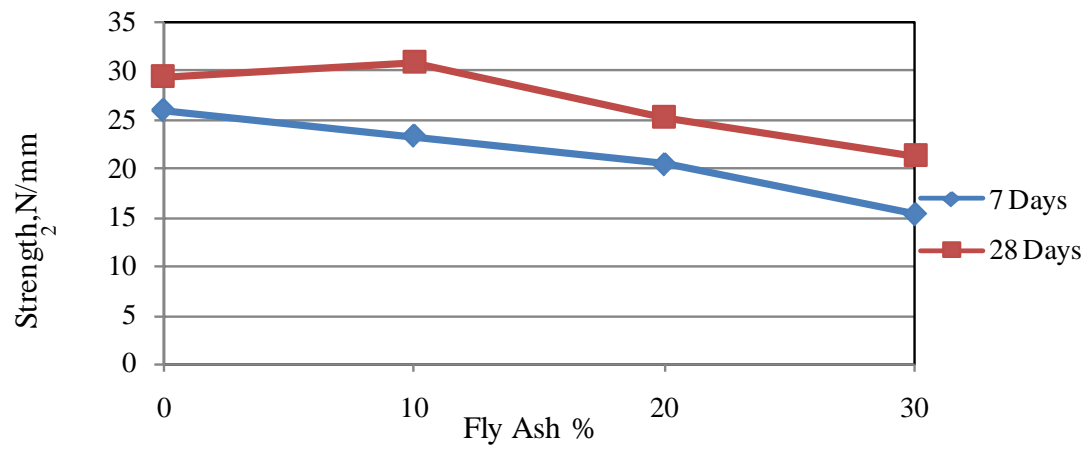

Figure 1. Concrete strength with fly ash.

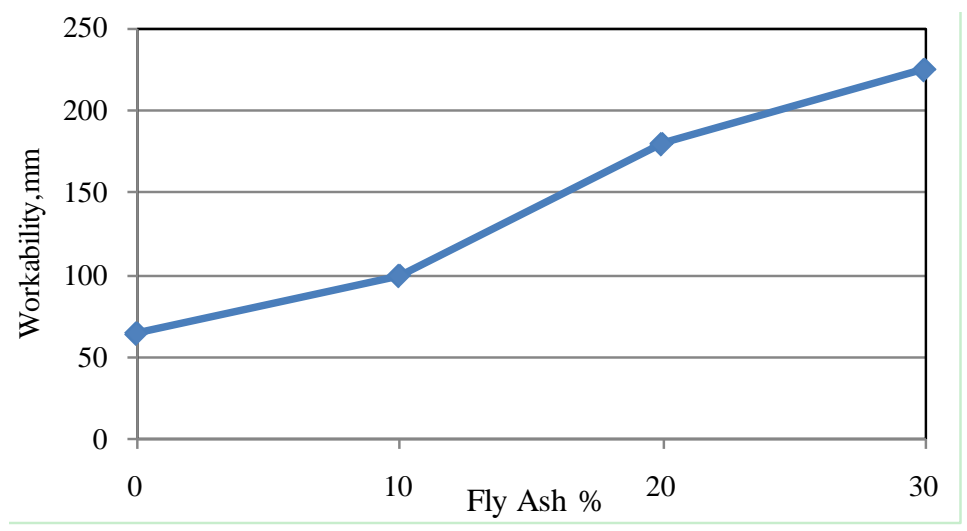

Figure 2. Concrete workability with fly ash.

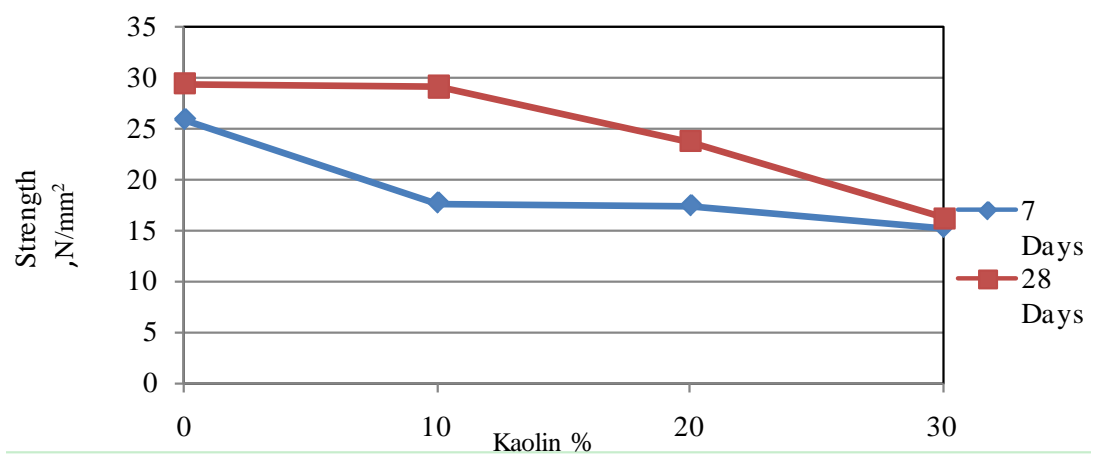

Figure 3. Concrete strength with kaolin. 


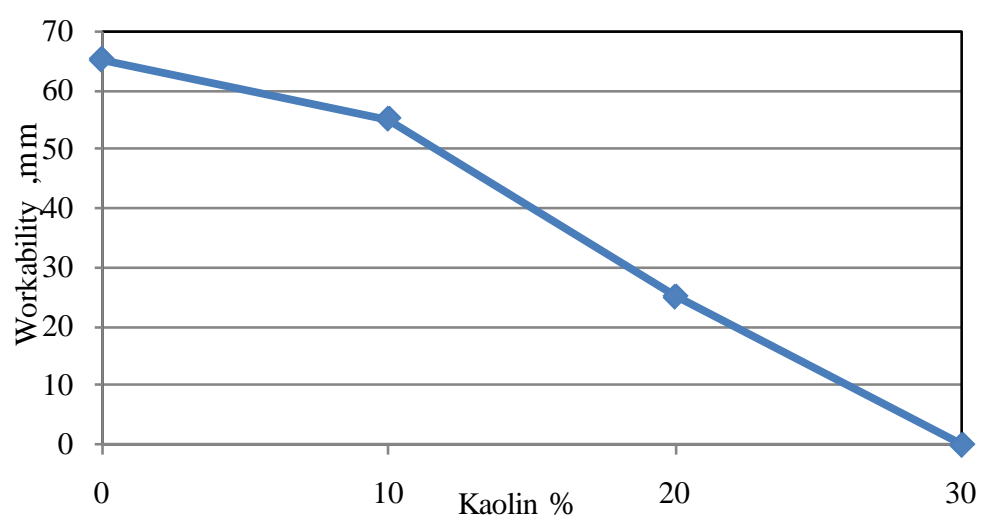

Figure 4. Concrete workability with kaolin.

cement, the calcium content was reduced and concrete strength as well. For kaolin samples there are no calcuim, so the $100 \%$ concrete pose highest strength.

Since Class F ash reacts slowly with water. The complete pozolana reactions will complete after long time, the strength of concrete cubes were high after 28 days. The results was agreed with other researcher that concerte class $\mathrm{F}$ fly ash have slow strength gain at early ages and delayed setting that results in extended curing time requirements [11].

The concrete workability which represents the mixture ability to fill the mold properly with the desired work, without reducing the concrete's quality, was increased with the addition of fly ash. The maximum workability was achieved at $30 \%$ fly ash.

For concrete-kaolin mixture the strength was reduced to $40.8 \%$ of the ummix concrete with the addition of $30 \%$ kaolin in 7 days. For the 28 days the strength reduction percent is $44.7 \%$ with $30 \%$ kaolin replacement.

Dramatic reduction in concrete workability was obtained with the increasing kaolin amount. With $30 \%$ kaolin the workability was approximately zero.

In general, small particle size of kaolin and fly ash with higher specific surface area are favorable to produce highly dense and impermeable concrete; however, they cause lower concrete workability.

\section{Conclusions}

The following conclusions are drawn on the use of fly ash and kaolin in concrete making:

1) The addition of fly ash for long life term improves the concrete strength.

2) Addition of $10 \%$ fly ash increases the concrete strength.

3) Higher fly ash cement replacement in concrete reduces the comprehensive strength.

4) The concrete workability is improved with fly ash addition.

5) The addition of Kaolin under study reduces the comprehensive strength and workability.

6) The fly ash improves the concrete properties better than kaolin. The fact is that the calcium and aluminum content in fly ash are higher than that in kaolin, which enhances the pozzolana reactions when the water is added to the fly ash concrete mix.

\section{Acknowledgements}

Authors are thankful to the Road and Building Research Institute, University of Khartoum-Sudan, for their great help during the experimental programme.

\section{References}

[1] Chang, T.-P., Chung, F.-C. and Lin, H.-C. (1996) A Mix Proportioning Methodology for High Performance Concrete. Journal of the Chinese Institute of Engineers, 19, 645-655. http://dx.doi.org/10.1080/02533839.1996.9677830

[2] ACI Committee 226 (1988) Use of Fly Ash in Concrete, ACI 226.3R-87. ACI Material Journal, 85, 381-408.

[3] ACI Committee 211 (1993) Guide for Selecting Proportions for High-Strength Concrete with Portland Cement and Fly Ash, ACI 226.4R. ACI Material Journal, 90, 272-283. 
[4] Langley, W.S., Carette, G.G. and Malhotra, V.M. (1989) Structural Concrete Incorporating High Volumes of ASTM Class F Fly Ash. ACI Material Journal, 86, 507-514.

[5] Carette, G., Bilodeau, A., Chevrier, R.L. and Malhotra, V.M. (1993) Mechanicalproperties of Concrete Incorporating High Volumes of Fly Ash from Sources in the U.S. ACI Material Journal, 90, 535-544.

[6] (2014) Using Fly Ash in Concrete. http://precast.org/

[7] Wild, S., Khatib, J.M. and Jones, A. (1996) Relative Strength, Pozzolanic Activity and Cement Hydration in Superplasticized Metakaolin Concrete. Cement and Concrete Research, 26, 1537-1544. http://dx.doi.org/10.1016/0008-8846(96)00148-2

[8] Bhimani, P. and Vyas, C.M. (2013) Performance of Concrete with China Clay (Kaolin) Waste. International Journal of Latest Trends in Engineering and Technology (IJLTET), 2, 49-54.

[9] Hwang, C.L., Lee L.S. and Lin, F.Y. (1996) Densified Mixture Design Algorithm and Early Properties of High Performance Concrete. Journal of the Chinese Institute of Civil Engineering and Hydraulic Engineering, 8, 217-229.

[10] Tanaka, H., Wingnarajah, S., Sugimoto, K., Ukida, K. and Ishii, M. (1992) Characteristics of Concrete Incorporating Sorted Fly Ash. 4th CANMET/ACI International Conference on the Use of Fly Ash, Silica Fume, Slag and Natural Pozzolans in Concrete, Istanbul, 971-986.

[11] Ardani, A. (2012) Evaluation of High-Volume, Fly Ash Mixtures (Paste and Mortar Components) Using a Dynamic Shear Rheometer and an Isothermal Calorimeter. FHWA Publication No. FHWA-HRT-12-062, NTIS Accession No. PB2012-112546, HRDI-10, (202) 493-3422. 
Scientific Research Publishing (SCIRP) is one of the largest Open Access journal publishers. It is currently publishing more than 200 open access, online, peer-reviewed journals covering a wide range of academic disciplines. SCIRP serves the worldwide academic communities and contributes to the progress and application of science with its publication.

Other selected journals from SCIRP are listed as below. Submit your manuscript to us via either submit@scirp.org or Online Submission Portal.
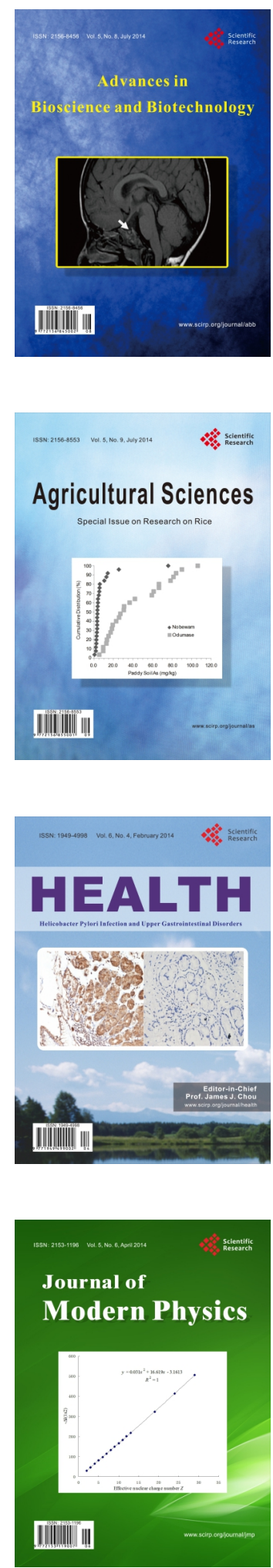
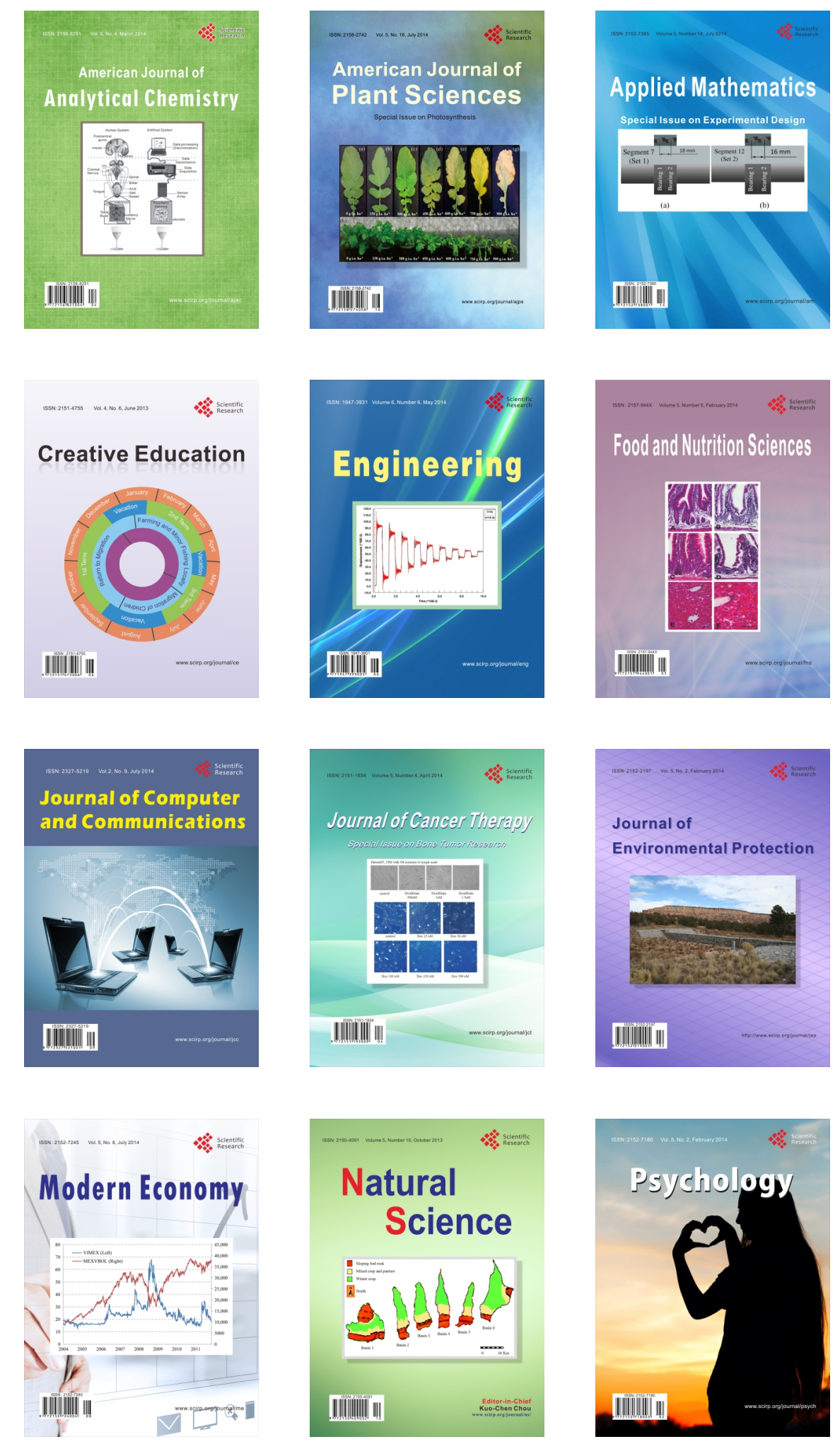